\title{
PENGARUH PELAKSANAAN PENDEKATAN PEMBELAJARAN MATEMATIKA REALISTIK TERHADAP PEMAHAMAN KONSEP PADA MURID SEKOLAH DASAR
}

\author{
Yusrianti \\ Guru Sekolah Dasar \\ Sekolah Negeri Mangkura Makassar \\ email: yusriantiyusuf@yahoo.com)
}

\begin{abstract}
ABSTRACK
This research purpose to (1) identify the process of the Implamention of realistic mathematics education, (2) knowing the understanding concept in mathematics of students (3) search the influence of the implementation of realistic mathematics education against the understanding concept of students. This research is the experiment research, True Experiment Design by using pre-test post-test control group design involve one experiment class and one control class. To know about the result of this research, researcher used observation sheet and essay instrument which has 8 numbers. Result of observation data analyze show that the implamention of realistic mathematics education in first meeting got percentage 69,84\% with enough categorized and increase in fourth meeting 96,82\% with very good categorized. The result of understanding concept data analyze show that there is different result of understanding concept of student between the experiment class and the control class significantly. The average of experiment's class score is 77,2, and the average of control's class score is 66,9. So, the experiment's class score is higher than the control's class score. As conclusion that the implementation of realistic mathematics education has given positive effect to the understanding concept of student.
\end{abstract}

Keyword: realistic mathematics education and understanding of concept

\begin{abstract}
ABSTRAK
Penelitian ini bertujuan untuk (1) mengidentifikasi proses pelaksanaan pendekatan pembelajaran matematika realistik, (2) mengetahui gambaran pemahaman konsep dalam pembelajaran matematika sebelum dan setelah penerapan pendekatan pembelajaran matematika realistik (3) menguji pengaruh pelaksanaan pendekatan pembelajaran matematika realistik terhadap pemahaman konsep. Jenis penelitian merupakan penelitian eksperimen true experiment design dengan melibatkan satu kelas eksperimen dan satu kelas kontrol, desain pre-testpost-test control group design. Hasil penelitian diketahui dengan menggunakan instrumen lembar observasi dan instrumen tes pemahaman konsep dalam bentuk tes uraian sejumlah 8 soal. Data di analisis secara deskriptif dan inferensial. Hasil analisis data observasi menunjukkan bahwa pelaksanaan pendekatan matematika realistik pada pertemuan pertama persentase 69,84\% dengan kategori cukup dan meningkat menjadi 96,82\% kategori sangat baik pada pertemuan keempat. Hasil anaisis data pemahaman konsep menunjukkan adanya perbedaan pemahaman konsep antara kelas eksperimen dan kelas kontrol yang signifikan. Nilai posttest pada kelas eksperimen rata-rata 77,2, sedangkan untuk nilai rata-rata kelas kontrol adalah 66,9 sehingga rata-rata kelas eksperimen lebih besar daripada kelas kontrol. Maka pelaksanaan pendekatan pembelajaran matematika realistik berpengaruh positif terhadap peningkatan pemahaman konsep.
\end{abstract}

Kata kunci: pendekatan pembelajaran matematika realistik, pemahaman konsep 


\section{PENDAHULUAN}

Matematika merupakan salah satu mata pelajaran pokok yang diajarkan di sekolah dasar. Menurut Depdiknas, 2006 bahwa tujuan pembelajaran matematika di sekolah dasar adalah agar peserta didik memiliki beberapa kemampuan, salah satunya adalah memahami konsep matematika, menjelaskan keterkaitan antar konsep, mengaplikasikan konsep atau algoritma secara luwes, akurat, efisien, dan tepat dalam pemecahan masalah.

Berdasarkan hal tersebut, pembelajaran matematika yang diajarkan di sekolah dasar harus bisa membuat murid memahami konsep matematika. Dengan belajar matematika murid diharapkan tidak hanya berkembang keterampilan berhitungnya, tapi bisa memiliki kemampuan memecahkan masalah yang meliputi kemampuan memahami masalah, merancang model matematika, menyelesaikan model dan menafsirkan solusi yang diperoleh.

Matematika merupakan suatu ilmu yang berhubungan dengan penelaahan bentuk-bentuk atau struktur-struktur yang abstrak dan hubungan di antara hal-hal itu. Untuk memahami strukturstruktur dan hubungan-hubungannya diperlukan pemahaman tentang konsep-konsep yang terdapat dalam matematika itu.

Namun pada kenyataannya, masih banyak anggapan bahwa matematika sulit dipelajari, tidak menyenangkan, membosankan, menakutkan dan sebagainya. Sikap ini tentu saja mengakibatkan pemahaman konsep matematika dan prestasi belajar terhadap matematika semakin merosot. Hal ini harus menjadi perhatian khusus dari para guru untuk melakukan suatu upaya agar dapat meningkatkan pemahaman konsep dan prestasi belajar matematika anak didiknya.

Untuk dapat membekali murid dengan penguasaan konsep yang memadai, kemampuan guru dalam menerapkan pendekatan pembelajaran yang membuat murid mudah menerimanya sangat diperlukan agar murid dapat menyenanginya. Untuk dapat membantu memudahkan murid memahami materi yang disajikan, pembelajaran matematika di sekolah dasar hendaknya tidak dilakukan ke arah abstrak, tetapi sedapat mungkin dilakukan dimulai dari konkret menuju abstrak, dari hal-hal yang mudah ke hal-hal yang sulit atau dari sederhana menuju ke kompleks.
Hasil pengamatan peneliti di sekolah dasar, masih banyak murid yang menganggap belajar matematika itu sulit. Hal ini disebabkan kurangnya pemahaman konsep murid dalam belajar matematika. Ada beberapa hal yang menjadi permasalahan dalam pembelajaran matematika khususnya dalam menanamkan konsep kepada murid, yaitu guru yang masih berperan aktif dalam menyampaikan materi pelajaran, sehingga pembelajaran menjadi monoton dan membosankan bagi murid. Murid hanya menerima pelajaran tanpa ada pengalaman dari murid itu sendiri sehingga pelajaran yang diterima dari guru hanya berupa konsep yang sulit dipahami oleh murid karena konsep matematika tidak langsung diperoleh dari pembentukan pengetahuan yang mereka temukan sendiri melainkan mereka hanya menerima dari gurunya saja sehingga murid lemah dalam memahami konsep matematika yang dipelajari. Hal ini sejalan dengan pendapat Ruseffendi (2006) yang menyatakan bahwa terdapat banyak murid yang setelah belajar matematika, tidak mampu memahami bahkan pada bagian yang paling sederhana sekalipun, banyak konsep yang dipahami secara keliru sehingga matematika dianggap sebagai ilmu yang sukar, ruwet, dan sulit.

Berdasarkan hasil observasi terhadap pelaksanaan pembelajaran matematika di sekolah, maka guru harus menerapkan pendekatan yang dapat membuat murid lebih mudah dalam memahami konsep matematika. Guru harus mengupayakan penciptaan lingkungan belajar matematika yang menyenangkan bagi murid sesuai dengan penggunaan konteks yang ada di lingkungan keseharian murid dan harus mengoptimalkan pengalaman yang dimiliki murid dalam memecahkan masalah sesuai dengan konteks yang ada di lingkungan keseharian murid.

Menurut Suherman (2001), pemberian pembelajaran matematika yang bermakna dan tidak memisahkan belajar matematika dengan pengalaman murid sehari-hari, murid akan dapat mengaplikasikan matematika dalam kehidupan sehari-hari dan tidak cepat lupa.

Pendekatan pembelajaran yang dapat membantu guru mengajarkan konsep matematika dengan baik adalah pendekatan pembelajaran matematika realistik. Penerapan pendekatan pembelajaran matematika realistik berpengaruh 
terhadap pemahaman konsep matematika pada murid.

Menurut Tarigan (2006), pembelajaran matematika realistik merupakan pendekatan yang orientasinya menuju kepada penalaran murid yang bersifat realistik sesuai dengan tuntutan Kurikulum Berbasis Kompetensi yang ditujukan kepada pengembangan pola pikir praktis, logis, kritis dan jujur dengan berorientasi pada penalaran matematika dalam menyelesaikan masalah.

Pendekatan pembelajaran matematika realistik memungkinkan guru mengaitkan antara materi pelajaran matematika yang diajarkan dengan konteks nyata yang ada di lingkungan sekitar murid, sehingga murid dapat lebih memahami untuk apa materi tersebut diajarkan.

Pendekatan pembelajaran matematika realistik memungkinkan guru untuk menciptakan lingkungan belajar yang menyenangkan dan bermakna bagi murid, karena materi yang diajarkan dikaitkan dengan kehidupan nyata yang sering dilihat bahkan dialami oleh murid, sehingga murid bisa dengan mudah memahami konsep yang diajarkan.

Berdasarkan latar belakang di atas, rumusan masalah yang dikaji dalam penelitian ini adalah :

1. Bagaimana pelaksanaan pendekatan pembelajaran matematika realistik di kelas $\mathrm{V}$ SDN Mangkura V Kota Makassar?

2. Bagaimana gambaran pemahaman konsep dalam pembelajaran matematika sebelum dan setelah penerapan pendekatan pembelajaran matematika realistik di kelas V SDN Mangkura V Kota Makassar?

3. Apakah ada pengaruh pelaksanaan pendekatan pembelajaran matematika realistik terhadap pemahaman konsep matematika di kelas V SDN Mangkura V Kota Makassar?

Berdasarakan rumusan masalah diatas, tujuan penelitian ini adalah:

1. Mengidentifikasi proses pelaksanaan pendekatan pembelajaran matematika realistik di kelas V SDN Mangkura V Kota Makassar

2. Mengetahui gambaran pemahaman konsep dalam pembelajaran matematika sebelum dan setelah penerapan pendekatan pembelajaran matematika realistik di kelas V SDN Mangkura V Kota Makassar
3. Menguji pengaruh pelaksanaan pendekatan pembelajaran matematika realistik terhadap pemahaman konsep dalam pembelajaran matematika di kelas V SDN Mangkura V Kota Makassar

\section{METODE PENELITIAN}

Jenis penelitian yang digunakan adalah True Eksperimen Design yaitu Pretest-Posttest Control Group Design. True Eksperimen Design merupakan rancangan yang menerapkan prosedur random pada partisipan untuk dimasukkan ke dalam kelas eksperimen dan kelas kontrol.

Desain penelitian yang digunakan adalah Pretest-Posttest Control Group Design. Penelitian ini adalah penelitian eksperimen yang melibatkan satu kelas eksperimen yang diajar dengan menggunakan pendekatan pembelajaran matematika realistik dan satu kelas kontrol yang diajar dengan tidak menggunakan pendekatan pembelajaran matematika realistik.

Pada penelitian ini terdapat dua variabel yaitu variabel bebas (independent variabel) dan variabel terikat (dependent variabel). Variabel bebas yaitu pelaksanaan pembelajaran matematika realistik dan variabel terikat yaitu pemahaman konsep.

Populasi dalam penelitian ini adalah murid kelas V SDN Mangkura V Kota Makassar. Populasi ditentukan sebanyak dua kelas yang terdiri dari 76 murid, yang akan dibagi menjadi dua kelas yaitu kelas eksperimen dan kelas kontrol.

Sampel dalam penelitian ini adalah 40 murid, yang diambil secara acak dari populasi sebanyak 76 murid. Jumlah 40 murid masingmasing terdiri dari 20 murid yang diambil untuk kelas eksperimen dan 20 murid yang diambil untuk kelas kontrol, teknik ini disebut dengan probability sampling dengan metode simple random sampling.

Teknik pengumpulan data yang digunakan dalam penelitian ini adalah tes pemahaman konsep. Tes dilaksanakan sebanyak dua kali, yaitu pre-test dan post-test. Pre-test dilaksanakan dengan tujuan untuk mengetahui pemahaman konsep awal murid pada kelas eksperimen dan kelas kontrol. Tes ini dilaksanakan sebelum kelas eksperimen dan kontrol menerima materi pelajaran dan perlakuan pendekatan pembelajaran matematika realistik. 
Post-test pada kelas eksperimen dan kelas kontrol bertujuan untuk mengetahui peningkatan atau penurunan pemahaman konsep pada murid setelah diberikan perlakuan pendekatan pembelajaran matematika realistik, dengan cara membandingkan dengan hasil pre-test.

Instrumen penelitian yang digunakan adalah lembar observasi pelaksanaan pendekatan pembelajaran matematika realistik dan tes pemahaman konsep matematika.

Intrumen berupa pedoman observasi yaitu lembar observasi pelaksanaan pendekatan pembelajaran matematika realistik. Lembar observasi pelaksanaan pendekatan pembelajaran matematika realistik didasarkan pada tahap-tahap yang ada pada rencana pelaksanaan pembelajaran (RPP) dan diobservasi oleh 1 orang yaitu oleh peneliti. Instrumen soal yang digunakan dalam penelitian ini adalah soal uraian berjumlah 8 soal. Soal terlebih dahulu diujicobakan dengan menggunakan teknik ujicoba lapangan di sekolah lain yang sejenis. Sebelum digunakan dalam penelitian, instrumen lembar observasi dan instrumen soal terlebih dahulu di validasi oleh ahli. Selain itu, instrumen soal telah dilakukan uji validitas dan uji realibilitas butir soal untuk mengetahui soal yang valid yang dapat digunaka untuk penelitian.

Data yang diperoleh dari sampel penelitian berupa data kuantitatif. Data tersebut dianalisis dengan analisis deskriptif dan teknik analisis statistik inferensial.

Analisis deskriptif dilakukan untuk mendeskripsikan pelaksanaan pendekatan pembelajaran matematika realistik terhadap pemahaman konsep murid. Menurut Safari (2003) data hasil pengamatan terhadap pembelajaran menggunakan kategorisasi persentase pencapaian yaitu:

a. Aktivitas belajar dikategorikan sangat baik (A) dengan persentase $85 \%-100 \%$.

b. Aktivitas belajar dikategorikan baik (B) dengan persentase $70 \%-84 \%$.

c. Aktivitas belajar dikategorikan cukup (C) dengan persentase 55\%-69\%.

d. Aktivitas belajar dikategorikan kurang (D) dengan persentase $40 \%-54 \%$.

e. Aktivitas belajar dikategorikan sangat kurang (E) dengan persentase 0\%-39\%.

Teknik analisis inferensial digunakan untuk menganalisis data sampel dan hasilnya diberlakukan untuk populasi. Analisis statistik inferensial yang digunakan dalam penelitian ini adalah uji hipotesis dan uji persyaratan analisis yang terdiri dari uji normalitas dan uji homogenitas.

Uji hipotesis dilakukan untuk mengetahui pengaruh penerapan pendekatan pembelajaran matematika realistik terhadap pemahaman konsep pada murid pada materi bangun ruang. Perhitungan dilakukan menggunakan uji-t (Independent Samples t-Test) dengan bantuan SPSS 20.0 for windows dengan taraf signifikansi 0,05 . Uji-t dilakukan apabila data terdistribusi normal dan homogen dengan ketentuan sebagai berikut: jika nilai sig. (2tailed) $>\alpha(0,05)$ maka $\mathrm{H}_{0}$ diterima (tidak terdapat pengaruh pendekatan pembelajaran matematika realistik terhadap pemahaman konsep murid); dan jika nilai sig. (2-tailed) $\leq \alpha$ $(0,05)$ maka $\mathrm{H}_{0}$ ditolak dengan syarat nilai mean kelas eksperimen lebih tinggi dibandingkan dengan nilai mean kelas kontrol (terdapat pengaruh pendekatan pembelajaran matematika realistik terhadap pemahaman konsep murid).

Analisis normalitas data menggunakan test of normality Kolmogorov-Smirnov dengan bantuan program SPSS 20.0 for windows pada taraf signifikansi $95 \%$ atau alpha $(\alpha) 0,05$; dengan ketentuan: apabila probabilitas atau nilai sig.(2-tailed) $\geq 0,05$, maka data berdistribusi normal; dan apabila $\leq 0,05$, maka data tidak berdistribusi normal. Uji homogenitas digunakan untuk menunjukkan bahwa dua kelompok data sampel berasal dari populasi yang memiliki varian sama.

Analisis test homogeneity of variance dengan Levene berbantuan program SPSS 20.0 for windows pada taraf signifikansi $95 \%$ atau alpha 0,05 dengan ketentuan apabila probabilitas atau nilai sig. (2-tailed) $\geq 0,05$ maka kedua varian populasi adalah homogen atau data berasal dari populasi yang mempunyai varians sama; dan apabila $\leq 0,05$ maka kedua varian tidak homogen.

\section{HASIL DAN PEMBAHASAN}

\section{Hasil}

Langkah-langkah pendekatan pembelajaran matematika realistik yang digunakan dalam penelitian ini meliputi lima tahap yaitu: mengajukan masalah realistik, mengidentifikasi masalah, menyelesaikan 
masalah realistik, mendiskusikan jawaban dan membuat kesimpulan.

Hasil observasi pelaksanaan pembelajaran pertemuan pertama, di kegiatan awal terdapat 1 kegiatan yang tidak terlaksana. Di kegiatan inti, terdapat 4 kegiatan yang tidak terlaksana. Di kegiatan akhir, 1 kegiatan tidak terlaksana. Adapun kegiatan pada kegiatan awal, inti dan akhir yang tidak terlaksana karena guru lupa melaksanakannya. Persentase pencapaian pada pertemuan pertama yaitu $69,84 \%$ dengan kategori penilaian cukup.

Pertemuan kedua, semua kegiatan pada kegiatan awal terlaksana. Di kegiatan inti terdapat 2 kegiatan tidak terlaksana. Pada kegiatan akhir, semua kegiatan terlaksana. Persentase pencapaian pada pertemuan kedua yaitu $80,95 \%$ dengan kategori penilaian baik.

Pertemuan ketiga, semua kegiatan pada kegiatan awal, kegiatan inti dan kegiatan akhir terlaksana. Persentase pencapaian pada pertemuan ketiga yaitu 90,47\% dengan kategori penilaian sangat baik.
Pada pertemuan keempat semua kegiatan pada kegiatan awal, kegiatan inti dan kegiatan akhir telah terlaksana. Persentase pencapaian pada pertemuan keempat yaitu $96,82 \%$ dengan kategori penilaian sangat baik.

Secara umum, semua langkah-langkah kegiatan pada setiap pertemuan dilaksanakan dengan baik oleh guru dan terjadi peningkatan persentase perolehan dari pertemuan pertama hingga pertemuan keempat dari kategori cukup pada pertemuan pertama meningkat menjadi kategori baik pada pertemuan kedua dan meningkat lagi menjadi kategori sangat baik pada pertemuan ketiga dan keempat.

Data hasil pemahaman konsep matematika pada murid berupa hasil tes pemahaman awal murid (pretest) dan hasil tes pemahaman akhir murid (posttest) kelas eksperimen dan kontrol yang dapat dilihat pada tabel 1.1

Data pretest dan posttest murid kelas eksperimen dan kontrol dapat dilihat pada tabel sebagai berikut:

Tabel 1.1 Hasil pretest dan posttes kelompok eksperimen dan kelompok kontrol

\begin{tabular}{|c|c|c|c|c|c|c|c|c|}
\hline \multicolumn{4}{|c|}{$\begin{array}{c}\text { Kelompok } \\
\text { Kontrol }\end{array}$} & \multirow{3}{*}{$\begin{array}{l}\text { Klasifikasi } \\
\text { Nilai dan } \\
\text { Kualifikasi }\end{array}$} & \multicolumn{4}{|c|}{$\begin{array}{l}\text { Kelompok } \\
\text { Eksperimen }\end{array}$} \\
\hline \multicolumn{2}{|c|}{$\begin{array}{c}\text { Pre } \\
\text { test }\end{array}$} & \multicolumn{2}{|c|}{$\begin{array}{l}\text { Post } \\
\text { Test }\end{array}$} & & \multicolumn{2}{|c|}{ Pre Test } & \multicolumn{2}{|c|}{ Post Test } \\
\hline $\mathrm{F}$ & $\%$ & $\mathrm{~F}$ & $\%$ & & $\mathrm{~F}$ & $\%$ & $\mathrm{~F}$ & $\%$ \\
\hline 0 & 0 & 5 & 25 & $\begin{array}{c}80-100 \\
\text { Sangat Baik }\end{array}$ & 0 & 0 & 10 & 50 \\
\hline 6 & 30 & & & $66-79,9$ & 5 & 25 & & \\
\hline 2 & 10 & 6 & 30 & $56-65,9$ & 3 & 15 & & \\
\hline 7 & 35 & 7 & 35 & & 4 & 20 & 4 & 20 \\
\hline & & 2 & 10 & Kurang & & & 1 & 5 \\
\hline 5 & 25 & 0 & 0 & $\begin{array}{c}0-39,9 \\
\text { Sangat Kurang }\end{array}$ & 8 & 40 & 0 & 0 \\
\hline 20 & 100 & 20 & 100 & Jumlah & 20 & 100 & 20 & 100 \\
\hline
\end{tabular}

Sumber: Hasil penelitian tahun 2016.

Berdasarkan Tabel 1.1 dapat diketahui bahwa nilai pretest kelas eksperimen mayoritas termasuk dalam kualifikasi sangat kurang dan kelas kontrol mayoritas termasuk dalam kualifikasi kurang. Kelas eksperimen sebanyak $40 \%$ (8 murid) termasuk kualifikasi sangat kurang, 20\% (4 murid) termasuk kualifikasi kurang, 15\% (3 murid) termasuk kualifikasi cukup dan $25 \%$ (5 murid) termasuk kualifikasi baik. Sedangkan kelas kontrol sebanyak 25\% (5 murid) termasuk kualifikasi sangat kurang, 35\%
(7 murid) termasuk kualifikasi kurang, 10\% (2 murid) termasuk kualifikasi cukup dan 30\% (6 murid) termasuk kualifikasi baik.

Hasil posttest murid pada kelas eksperimen lebih banyak berada pada kualifikasi sangat baik, sedangkan kelas kontrol lebih banyak murid berada pada kualifikasi cukup. Kualifikasi kelas eksperimen mengalami kenaikan dari baik menjadi sangat baik, sedangkan kelas kontrol mengalami kenaikan dari kualifikasi kurang menjadi cukup. Persentase terbesar kelas eksperimen yaitu $50 \%$ 
(10 murid) termasuk kualifikasi sangat baik, 25\% (5 murid) termasuk kualifikasi baik, 20\% (4 murid) termasuk kualifikasi cukup dan 5\% (1 murid) termasuk kualifikasi kurang. Hasil tersebut berbeda dengan kelas kontrol, hasil posttest kelas kontrol sebanyak 25\% (5 murid) termasuk kualifikasi sangat baik, 30\% (6 murid) termasuk kualifikasi baik, $35 \%$ (7 murid) termasuk kualifikasi cukup dan 10\% (2 murid) termasuk kualifikasi kurang.

Hasil pretest, rata-rata kelas kontrol 48,45 sedangkan kelas eksperimen 50,8. Hasil posttest, rata-rata kelas kontrol 66,9 sedangkan kelas eksperimen 77,2 . Perbedaan rata-rata yang besar tersebut menunjukkan pendekatan pembelajaran matematika realistik berpengaruh untuk meningkatkan pemahaman konsep pada murid.

Hasil output uji hipotesis diperoleh $t_{\text {hitung }}=2,465>$ daripada $t_{\text {tabel }}=0,878$ pada taraf signifikan $\alpha=0,05$, berarti ada perbedaan pemahaman konsep antara kelas eksperimen dan kelas kontrol. Sehingga dapat disimpulkan bahwa ada perbedaan yang bermakna antar nilai posttest kelas eksperimen dengan nilai posttest kelas kontrol, atau dengan kata lain $\mathrm{H}_{0}$ ditolak dan $\mathrm{H}_{1}$ diterima.

\section{Pembahasan}

Pelaksanaan pendekatan pembelajaran matematika realistik secara umum langkahlangkah kegiatan pada setiap pertemuan dilaksanakan dengan baik oleh guru, terlihat dari meningkatnya persentase perolehan dari pertemuan pertama hingga pertemuan keempat. Pada pertemuan pertama, pelaksanaan pembelajaran matematika realistik mendapat kategori penilaian cukup, meningkat pada kegiatan kedua dengan mendapat kategori penilaian baik dan meningkat lagi pada pertemuan ketiga dan keempat dengan kategori penilaian sangat baik. Peningkatan ini terjadi dikarenakan adanya refleksi yang dilakukan oleh peneliti dan guru yang dilakukan pada setiap akhir pertemuan pembelajaran.

Data penilaian pemahaman konsep matematika yang terdiri dari data pretest dan posttest yang diperoleh melalui tes berupa soal uraian sebanyak 8 soal. Data hasil penelitian menunjukkan terjadi peningkatan yang signifikan antara nilai pretest dan posttest pada kelas eksperimen yang diberi perlakuan pendekatan pembelajaran matematika realistik. Peningkatan tersebut lebih besar dibandingkan dengan nilai pretest dan posttest pada kelas kontrol yang tidak diberi perlakuan pendekatan pembelajaran matematika realistik.

Pemahaman konsep matematika materi bangun ruang pada kelas eksperimen terjadi peningkatan yang signifikan, dari nilai rata-rata pretest yaitu sebesar 50,8 menjadi 77,2 pada nilai rata-rata posttest. Peningkatan nilai rata-rata tersebut lebih signifikan jika dibanding dengan kelas kontrol dengan nilai rata-rata pretest 48,45 menjadi 66,9 pada nilai rata-rata posttest. Hasil ini menunjukkan bahwa pelaksanaan pendekatan pembelajaran matematika realistik berpengaruh terhadap peningkatan pemahaman konsep pada murid.

Untuk mengetahui adanya pengaruh pelaksanaan pendekatan pembelajaran matematika realistik terhadap pemahaman konsep murid, dapat dengan membandingkan nilai rata-rata pemahaman konsep yang diperoleh. Nilai yang diperoleh dari hasil tes pemahaman konsep selama kegiatan pembelajaran setiap pertemuan pada kelas eksperimen mengalami peningkatan secara singnifikan sedangkan kelas kontrol juga mengalami peningkatan tetapi tidak singnifikan.

Temuan penelitian ini menunjukkan bahwa pembelajaran matematika dengan pendekatan pembelajaran matematika realistik berpengaruh terhadap pemahaman konsep pada murid. Pengaruh tersebut disebabkan oleh karena murid kelas eksperimen lebih dapat mendefinisikan konsep dan membuat contoh dan bukan contoh daripada kelas kontrol. Murid dapat mengidentifikasi konsep dengan mengenal syarat-syarat yang menentukan suatu konsep. Hal ini merupakan salah satu indikator dari pemahaman konsep matematika. Selain itu, pembelajaran menjadi lebih menyenangkan dan bermakna bagi murid, ditunjukkan dengan banyak murid yang merasa senang dan mengingat lama materi yang telah diberikan.

\section{SIMPULAN DAN SARAN}

Pelaksanaan pendekatan pembelajaran matematika realistik yang terdiri dari tahap mengajukan masalah realistik, mengidentifikasi masalah, menyelesaikan masalah realistik, mendiskusikan dan menarik kesimpulan pada umumnya terlaksana dengan baik. Pelaksanaan 
pendekatan pembelajaran matematika realistik terjadi peningkatan dari pertemuan pertama hingga pertemuan keempat. Peningkatan terlihat dari kualifikasi penilaian cukup pada pertemuan pertama, meningkat menjadi kualifikasi baik pada pertemuan kedua dan meningkat lagi menjadi kualifikasi sangat baik pada pertemuan ketiga dan keempat.

Pemahaman konsep pada murid dalam pembelajaran matematika sebelum pelaksanaan pendekatan pembelajaran matematika realistik pada umumnya berada pada kategori sangat kurang dan kurang, baik pada kelas eksperimen dan pada kelas kontrol. Setelah diberi perlakuan pelaksanaan pendekatan pembelajaran matematika realistik, pemahaman konsep pada murid kelas eksperimen meningkat pada kategori baik dan sangat baik sedangkan pada murid kelas kontrol meningkat pada kategori cukup dan baik.

Terjadi peningkatan pemahaman konsep yang signifikasn pada murid kelas eksperimen setelah diberikan perlakuan pendekatan pembelajaran matematika realistik. Pada kelas kontrol terjadi peningkatan pemahaman konsep namun tidak begitu signifikan. Peningkatan pemahaman konsep pada murid terlihat dari nilai hasil posttest yang meningkat dari sebelum adanya perlakuan. Pelaksanaan pendekatan pembelajaran matematika realistik berpengaruh terhadap pemahaman konsep pada murid kelas $\mathrm{V}$ SDN Mangkura V Kota Makassar.

Sesuai dengan kesimpulan, maka dapat diajukan beberapa saran yaitu guru hendaknya menggunakan pendekatan pembelajaran matematika realistik sebagai alternatif pendekatan pembelajaran untuk meningkatkan pemahaman konsep pada murid, Kepala sekolah hendaknya berperan sebagai inisiator agar guru menggunakan pendekatan pembelajaran matematika realistik pada pembelajaran terutama pada materi dengan kompetensi dasar yang menuntut murid dapat memahami konsep dengan baik dan peneliti selanjutnya agar mengujicobakan pendekatan pembelajaran matematika realistik pada materi yang sama di sekolah lain yang kemampuan awal murid lebih rendah.

\section{DAFTAR RUJUKAN}

Depdiknas. 2006. Kurikulum Tingkat Satuan Pendidikan (KTSP). Mata Pelajaran
Matematika Untuk Tingkat SD/MI. Jakarta Depdiknas.

Ruseffendi, E.T. 2006. Pendidikan Matematika 3 modul 1-9. Jakarta: Depdikbud Proyek Pembinaan Tenaga Kependidikan Tinggi.

Safari. 2003. Evaluasi Pembelajaran. Jakarta: Departemen Pendidikan Nasional Direktorat Jenderal Pendidikan Dasar dan Menengah Direktorat Tenaga Kependidikan.

Suherman. 2001. Strategi Pembelajaran Matematika Kontemporer. Bandung: Jurusan Pendidikan Matematika FMIPA Universitas Pendidikan Indonesia.

Tarigan, Daitin. 2006. Pembelajaran matematika realistik. Jakarta: Depdiknas Direktorat Jenderal Pendidikan Tinggi Direktorat Ketenagaan. 